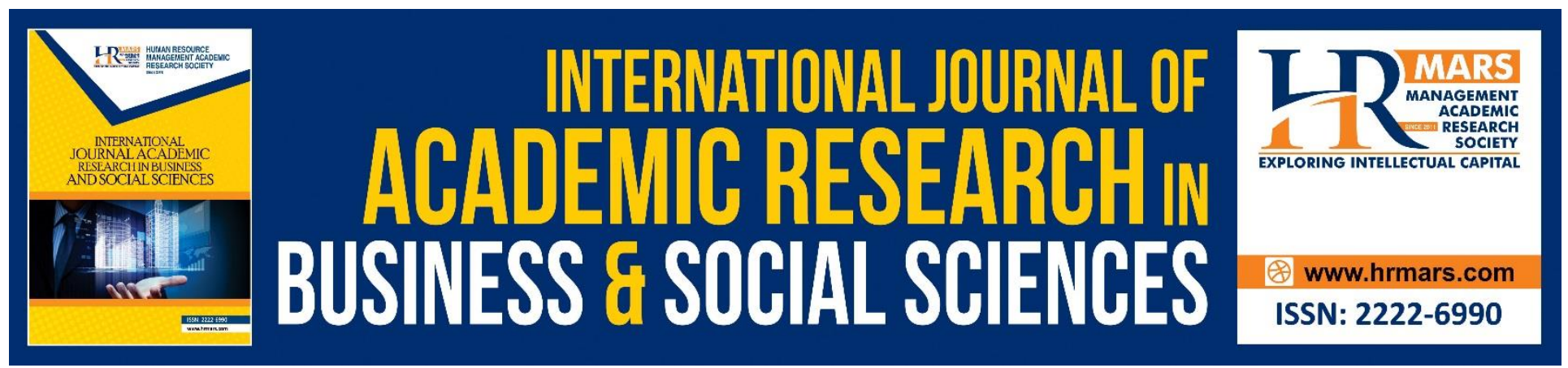

\title{
Adoption of Open Source Software (OSS) and Organization Performance in the Library
}

\section{Mohammad Fazli Baharuddin, Tengku Adil Tengku Izhar \& Mohd Shamsul Mohd Shoid}

To Link this Article: http://dx.doi.org/10.6007/IJARBSS/v8-i9/4591

DOI: $\quad 10.6007 /$ IJARBSS/v8-i9/4591

Received: 11 August 2018, Revised: 22 September 2018, Accepted: 29 September 2018

Published Online: 13 October 2018

In-Text Citation: (Baharuddin, Izhar, \& Shoid, 2018)

To Cite this Article: Baharuddin, M. F., Izhar, T. A. T., \& Shoid, M. S. M. (2018). Adoption of Open Source Software (OSS) and Organization Performance in the Library. International Journal of Academic Research in Business and Social Sciences, 8(9), 285-297.

\section{Copyright: (C) 2018 The Author(s)}

Published by Human Resource Management Academic Research Society (www.hrmars.com)

This article is published under the Creative Commons Attribution (CC BY 4.0) license. Anyone may reproduce, distribute, translate and create derivative works of this article (for both commercial and non-commercial purposes), subject to full attribution to the original publication and authors. The full terms of this license may be seen

at: http://creativecommons.org/licences/by/4.0/legalcode

Vol. 8, No. 9, September 2018, Pg. 285 - 297

http://hrmars.com/index.php/pages/detail/IJARBSS

JOURNAL HOMEPAGE

Full Terms \& Conditions of access and use can be found at http://hrmars.com/index.php/pages/detail/publication-ethics 


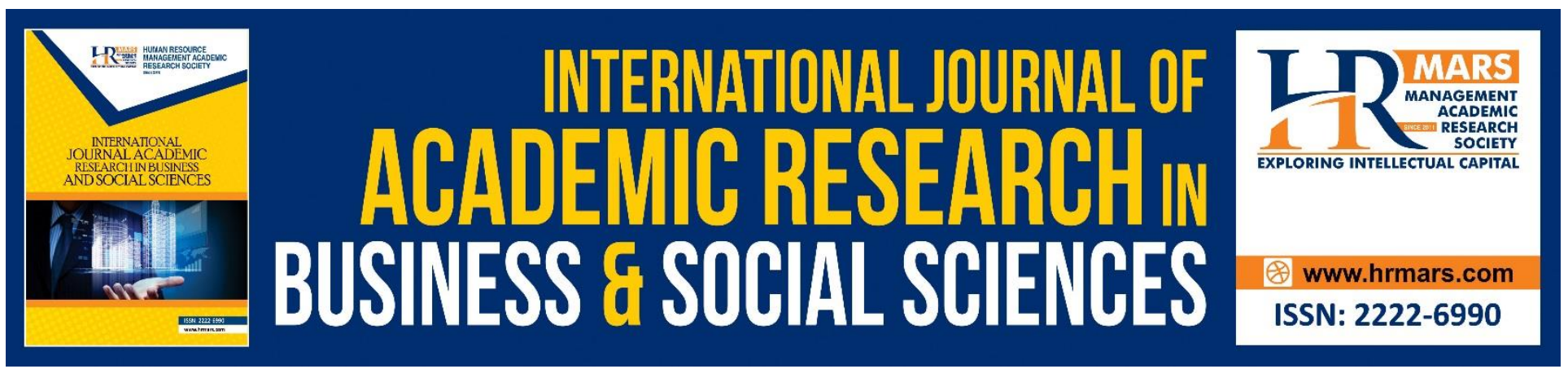

\title{
Adoption of Open Source Software (OSS) and Organization Performance in the Library
}

\author{
Mohammad Fazli Baharuddin, Tengku Adil Tengku Izhar \& Mohd \\ Shamsul Mohd Shoid \\ Faculty of Information Management, Universiti Teknologi MARA (UiTM), UiTM Selangor, \\ Shah Alam, Selangor \\ E-mail: fazli811@puncakalam.uitm.edu.my
}

\begin{abstract}
The emergence of OSS for the library, it has introduced a lot of new concept of managing the library and change the way in library daily operations. Open Source Software has become increasingly popular in libraries and every year more libraries migrate from proprietary software to open source software because of two main reasons, cost and functionality of the system. However, it is important for organization to be carefully during selection and customization an appropriate OSS as it might address specific business requirement in relation to the organizational performance. In this paper, the proposed framework will associate organization competitive edge throughout their ability to improve their performance. In shortcoming, this paper focuses the dimensions of OSS adoption and relationship with organizational performance.
\end{abstract}

Keywords: Open Source Software; Organization Performance; Library

\section{INTRODUCTION}

The initiation of advanced information communication technologies (ICTs) and emergence of industry 4.0 represents the significant changes and opportunity for every organization in various industries. This includes the acceptance of ICT in every aspect of operations that facilitates the delivery process. It has bigger impacts on added value for organization especially in productivity and efficiency (Chengalur-smith, Nevo, \& Demertzoglou, 2010). Nevertheless, ICT facilities were developed involves a high cost in term of software and applications and it is significant constraint for organization. Up until the emergence of Open Source Software (OSS) is available free of cost on the internet (Oyelude, 2016). OSS can be downloaded as free and can be improved and modified. OSS is managed by protecting the creators or founder through a licensing process. This is a great opportunity for the organization, including libraries to use OSS extensively to assist every process and operation. In order to ensure that the library continues to remain relevant and to guarantee services offered always meet the customer needs, libraries need to be more sensitive to the development and growth of the ICT including OSS developments. The emergence of OSS for the library, it has introduced a lot of new concept of managing the library and change the way in library daily operations (Mijinyawa \& 
Abdulwahab, 2014; Randhawa, 2008; Uzomba, 2015). Basically, OSS associated zero acquisition cost with a license authorizing of the software to be improved and re-distributed to third parties (Murphy \& Cox, 2015). This contrasts with proprietary software which comes with strict license conditions regarding use and distribution (Thanasopon, 2015). Open Source Software has become increasingly popular in libraries and every year more libraries migrate from proprietary software to open source software because of two main reasons, cost and functionality of the system (Singh, 2013). According to Randhawa (2008), there are four basic functions or processes in the library services which has been adopted OSS; 1) Library Automation, 2) Institutional Repository, 3) Web Publishing, 4) Operating System.

In 2002, the Government of Malaysia has decided to encourage the adoption of OSS in the Public Sector (MAMPU, 2006). The Malaysian Administrative Modernization and Management Planning Unit (MAMPU) of the Prime Ministers Department is entrusted to lead and implement this OSS Initiative. Meanwhile, in 2004 the Malaysian Public Sector OSS Master Plan (OSS Master Plan) was published together with the launching of the Open Source Competency Centre (OSCC). Within the Master Plan, the OSS Framework was designed and developed to provide guidance for its implementation. In line with the framework, seven (7) strategic thrusts were identified that defined the high level implementation action plan of the OSS Initiative:

1. Develop OSS Technical Implementation Plan for the Public Sector

2. Entrust a governing body to champion, monitor \& drive OSS implementation

3. Train and develop human resource to support OSS implementation

4. Promote creativity and innovativeness via $R \& D$ to harness competitiveness

5. Continuous development of policies \& legal direction to encourage utilization and production of OSS

6. Provide incentives to prosper the development of OSS solutions

7. Optimize resources by encouraging smart partnerships with relevant organizations

The vision for OSS in the Malaysian Public Sector is to create and enhance value by using OSS within the Public Sector ICT framework in providing efficient and quality services (MAMPU, 2006). The Government of Malaysia will implement OSS wherever it indicates to be the most appropriate option. It is envisioned by the GOM that all Public Sector agencies will align their respective ICT plans, resources and actions towards achieving objectives of the OSS Initiative, that are to reduce total cost of ownership, increase freedom of choice of software usage, increase interoperability among systems, increase growth of the ICT industry, increase growth of the OSS industry, increase growth of OSS user and developer community, increase growth of knowledge-based society and reduce digital divide. The ultimate goal is the agencies are competence to develop and implement OSS solution independently.

However, until end of 2010 statistic shows that only two OSS solution area which are desktop and infrastructure solutions contribute the biggest number of OSS adoption in Malaysia public sector agencies. Another four OSS solution areas which are application, workload consolidation, high performance computing and distributed enterprise are still at low number of adoption (Jusoh, Chamili, Yahaya, \& Pa, 2012). Meanwhile according to Hamid, Abdullah and Idrus (2016), from the total of 691 public sector agencies that have implemented OSS, only 192 public sector agencies $(27.8 \%)$ have implemented three solution areas or more with "some form of e-government services 
INTERNATIONAL JOURNAL OF ACADEMIC RESEARCH IN BUSINESS AND SOCIAL SCIENCES

Vol. 8, No. 9, Sept. 2018, E-ISSN: 2222-6990 @ 2018 HRMARS

and the lowest denominator being a website". Another 499 public sector agencies (72.2\%) have implemented only one or two solution areas. This analysis clearly shows that OSS implementation is low and OSS solutions are not fully utilized by the public sector agencies in Malaysia.

In the library, most of process and services can be discouraging if it is done manually (Bindura, 2018). Due to the beginning of OSS, various library management systems are now used to organize library materials (Reddy, 2013). There are a number of benefits that can be enjoyed by a library when it adopts OSS when automating its library services. Hanumappa, Dora and Navik (2014) state that the benefits include but are not limited to lower costs, no vendor lock in, adaption and innovation, and support through user communities and discussion groups (Reddy, 2013). The librarians would have greater control of their environments if they adopt OSS since they can tailor make the software to meet their respective needs. In shortcoming, this paper focuses the dimensions of OSS adoption and relationship with organizational performance.

\section{LITERATURE REVIEW}

The Information Communication Technology (ICT) has become significant for almost every organization including library. Hence, with ICT, such things as electronic cataloguing, electronic online public access catalogues (OPACs), electronic acquisition and serials control, electronic circulation functions, electronic distribution of commercial publications, electronic availability of raw data, multimedia information delivery systems, digitized collections and online textbooks are all now practicable with a higher degree of organization satisfaction (Ani, Esin, \& Edem, 2005). Furthermore, the rapid transformation of the ICT infrastructure has created new opportunities and challenges for traditional libraries such that the new trend is to move towards digital collection. Existing libraries are busy digitizing their traditional collections via online subscriptions and planning, design, deployment and ongoing operations management and technical support of ICT infrastructure (Awuor, Rabah, \& Maake, 2016). Therefore, the emergence of the OSS has greatly benefited the organization. OSS are available free of cost using which the information in electronic, digital forms can be easily tagged, classified and managed. While free software can only be freely used, the OSS are provided for free for use, modification and distribution by all (Leeladharan, 2015).

According to Alex (2015), organizations are increasingly using information technology to develop solutions to business problems, to improve both the efficiency and effectiveness of the decisionmaking process, to enhance productivity and service quality, to achieve dynamic stability, and compete for new markets. However, usually most of organization will select proprietary software as a first option in supporting organization operation whereby users must pay for the right to use software with strict restrictions and no access to source code (Marsan \& Paré, 2013). In addition, most of organizations are having critical issues regarding financial allocation. As a result, libraries are the last departments to be considered in allocating funds as institutions are talking about cost cutting measures and budget cuts from the ministries (Bindura, 2018; Hanumappa et al., 2014; Mutula, Kalaote, \& Mutula, 2010). Faced with such situations of unavailability of funds, libraries have to provide the services to the clientele so that they are able to answer their various information needs using the emerging technologies. OSS is the best option that library has. 
INTERNATIONAL JOURNAL OF ACADEMIC RESEARCH IN BUSINESS AND SOCIAL SCIENCES Vol. 8, No. 9, Sept. 2018, E-ISSN: 2222-6990 @ 2018 HRMARS

\section{Open Source Software (OSS)}

The terms "Open Source Software" (OSS), "free Software", "Free Open Source Software" (FOSS), and "Free/Libre Open Source Software" (FLOSS) are often used interchangeably (Jusoh et al., 2012). The difference was at the license agreements which free software generally licensed with GNU General Public License (GPL) while OSS may use some other license or GPL. The source-code of OSS is released with the binary. Users and developers can be licensed to use and modify the code, and to distribute any improvements they make. However, the term 'free' was often misunderstood to mean 'no cost'. Hence 'open source software' was coined as a less contentious and more' business-friendly' term. According to the Wei (2011), 'free' should not be understood as "free-of-charge" but rather as the user's freedom:

- To run the program for any purpose.

- To study how the program works and to adapt it to a specific need.

- To redistribute copies of the original or of the modified program.

- The freedom to improve the program and release your improvements to the public so that the whole community benefits.

The history of OSS began with the establishment of The Free Software Foundation in 1985 founded by Richard Stallman to support the free software movement, which promotes the universal freedom to study, distribute, create, and modify computer software through its own General Public License (Anjaneyulu, Biradar, Gopinath, \& Naik, 2017).

Many of academic libraries are focusing on automation but are not aware of the use and benefits of OSS such as Koha, Dspace and Joomla in information management despite its numerous advantages. For instance, academic libraries in Nigeria that have introduced automation and integrated library systems made use of proprietary software such as Alice and Alexandra. This is because library management and librarians do not have knowledge about the open source software and how it works (Njoku, 2017). OSS has different functions such as operating systems, library management system, digital library / institutional repository, learning management system and content management (Hanumappa et al., 2014; Njoku, 2017). The reason OSS has been so successful is that it provides users with flexibility to choose the technology best suited for their needs without being tied to a particular vendor solution. The license-free and royalty-free nature of OSS reduces the capital costs of creating new solutions. And finally the open development of well-run open source projects allows many different organization to participate in the quality control and future development of the technology (Eclipse Foundation, 2017). However, a number of studies show that it is not clear how exactly the current state of OSS adoption specifically in Malaysia is. According to Yaseen and Bahari (2014) OSS adoption in ASEAN countries has approached the issue, unfortunately, the research is severely limited as it only examines whether government agencies in the region used OSS in their web server applications and not what might have been the drivers influencing software adoption. A study has also shown that the OSS adoption rate is still low within public sector organizations in Malaysia and the implementation of OSS also is still scant because the absence of certain factors (Hamid et al., 2016).

\section{Determinants of OSS Adoption}

In every decision to adopt OSS as information system in supporting organization operation, many things need to be considered. This is because every OSS developed with different functions. This 
includes referring to the organization that has ever used it. Previous studies have been done to investigate the antecedents of OSS adoption in organization. In 2006, Open Source Software (OSS) Implementation Guidelines has been produced (MAMPU, 2006). The objective of the OSS Adoption Guidelines is to assist the process of adoption of OSS and its success within the Public Sector in Malaysia. To this end, Public Sector agencies are required to consider adopting OSS in their respective agencies in accordance with the OSS Master Plan, this document and the agencies ICT Strategic Plan (ISP). Within the OSS Master Plan, potential areas in which OSS can be deployed have been categorized into six (6) solution areas, namely:

1. Workload Consolidation

2. High Performance Computing

3. Distributed Enterprise

4. Application Solution

5. Infrastructure Solution

6. Desktop Solution

Previous study by Yaseen and Bahari (2014) mentioned that organization size, cost, human resources, management support, user resistance and technological benefits are influencing factors for OSS adoption. According to Gurusamy and Campbell (2011), compatibility issues, economic value, standard of documentation, organizational environment, legal issue, product quality, user impacts and data conversion are the main focus in adopting OSS. Findings from this study show that decisions to adopt OSS applications appear influenced by the compatibility of the software with existing organizational technology and skills. Compatibility in terms of Availability of Support and Compatibility issues with OSS was found to be an inhibitor to OSS adoption. Meanwhile, Gichira, Miriti, and Kahonge (2012); Johnston, Begg, and Tanner (2013) were focusing on technology, organizational and environment context as factors that appear to facilitate or inhibit the adoption of OSS in organizations emerge.

\section{Organizational Performance}

The system that used modern technologies can present information to users in comprehensive format enabling them to use information systems effectively and improve the performance, high quality of the system leads to high quality of the information. The high quality of information helps organizations in managing their business processes, making decisions and improves organizational performance. Study by Al-mamary, Shamsuddin, and Aziati (2014) identified six variables or components of information system success: system quality, information quality, use, user satisfaction, individual impact, and organizational impact. Moreover organizational impact is the effect of information system on organizational performance. There are a lot of items for measure the organizational impact such as staff reduction, overall productivity gains, increased revenues, increased sales, increased profits, increased work volume, product quality, and contribution to achieving goals etc. Moreover organizational performance is accumulated end results of all the organization's work processes and activities (Al-mamary et al., 2014b; Jean, Sinkovics, \& Kim, 2008; Yunis, Tarhini, \& Kassar, 2017). Meanwhile, organizational performance is measured by using items such as productivity, efficiency, profitability, market value, competitive advantage, cost reduction, revenue enhancement, and overall organization performance (Al-mamary, Shamsuddin, \& Aziati, 2014a). It supported by Chengalur-smith et al. (2010), OSS may demonstrate their organization value in several ways including productivity, efficiency, reliability, and security. According to Yunis et al. 
INTERNATIONAL JOURNAL OF ACADEMIC RESEARCH IN BUSINESS AND SOCIAL SCIENCES Vol. 8, No. 9, Sept. 2018, E-ISSN: 2222-6990 @ 2018 HRMARS

(2017) ICT adoption is positively related to organizational performance. In the library, the use of information system is very important in supporting the organization's performance. It supported by Oguche (2017) whereby $90 \%$ of the respondents indicated that digitization, registration of library users, publications; ordering of information resources; generation of user statistics, storage of information resources; accessioning of information resources and marketing of library and information products and services were the duties with the highest impact of OSS implementation in all the federal university libraries studied.

\section{DEVELOPING PROPOSED FRAMEWORK}

In order to develop the proposed framework, several theories, models and frameworks of the OSS adoption as well as organizational performance have been reviewed. There are numerous wellestablished theories, models and frameworks in the OSS literature, which conclude and describe the relationship between OSS adoption and organizational performance. Study by Gichira et al. (2012) focuses on how and why OSS software is being adopted and implemented within organizations in Kenya. The researcher has adopted Technology Organization Environment (TOE) that use as a fundamental approach to investigating a firm context that influences the process by which it adopts, implements, and diffuses technological innovations. The TOE framework identifies three aspects to firm decision-making behavior for technological innovations: technological context, organizational context, and environmental context. Technological context includes both the internal and external technologies used by the firm. Meanwhile, organizational context refers to descriptive characteristics of the organization, including firm size and scope, complexity of firm managerial structure, and quality and degree of its human resources while environmental context refers to the firm industry and its dealings with trading partners, competitors and government.

Figure 1:

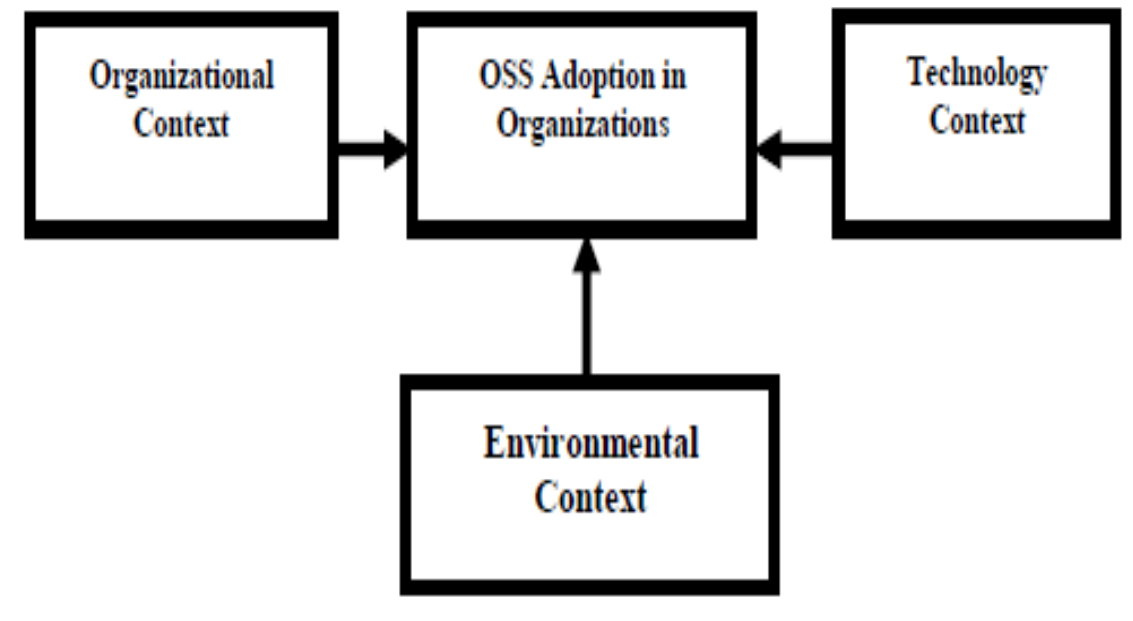

Environment (TOE)

Technology

Organization

However, individual factors which are not part of the TOE framework are being an important aspect of OSS adoption (Johnston et al., 2013). The TOE model defines a "context for change" which interacts with one another to influence technological innovation decision-making such as the adoption of OSS and impact on organizational performance. 
INTERNATIONAL JOURNAL OF ACADEMIC RESEARCH IN BUSINESS AND SOCIAL SCIENCES Vol. 8, No. 9, Sept. 2018, E-ISSN: 2222-6990 @ 2018 HRMARS

Meanwhile, study by Yaseen and Bahari (2014) focuses on Fitzgerald framework because it's considered the most comprehensive framework that include all possible factors. Purpose of the study is to identify the factors that may influence the OSS adoption decision and process in both the management level and the user level in Malaysian University Information and Communications Technology Centers. There are four components that would affect towards the OSS adoption. This includes managerial intervention, subjective norms, and facilitating conditions which occur at an organizational level. On the other hands, uncertainty avoidance factor is the only component that occurs in a country level that seems to affect the OSS adoption. Figure 2 shows the connection of these four components on OSS adoption.

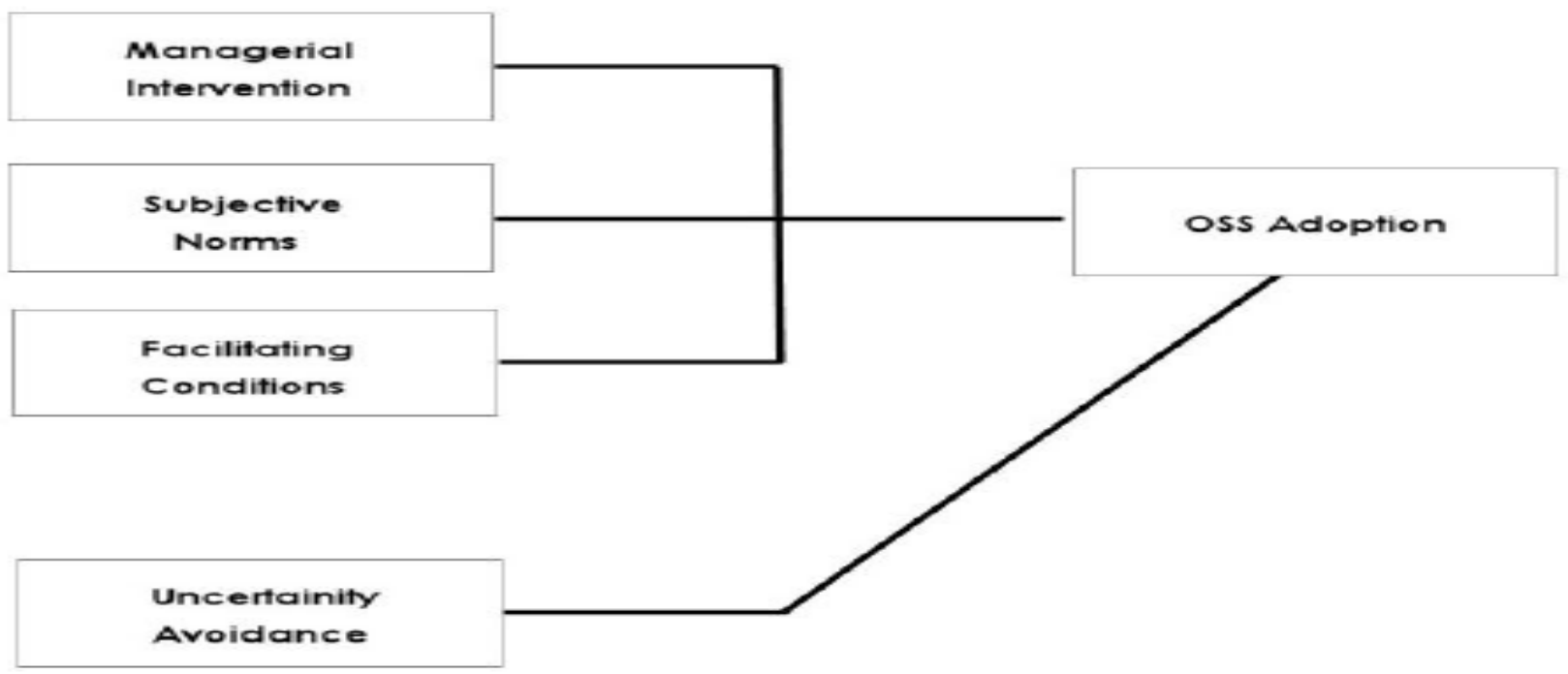

Figure 2: Fitzgerald Framework

Study by Al-mamary et al. (2014a) focuses on Management Information System (MIS) adoption in organizations. Synthesizing from the literature and interviews with some of the employees of telecommunications companies in Yemen, this study proposes a theoretical framework that takes into consideration the technological, organizational and people dimensions that might affect MIS adoption in organizations. Finding shows MIS provides several benefits to the business organization: to come out with appropriate responses to a business situation; the means of effective and efficient coordination between different departments at all the levels of the organization; access to relevant data and documents; use of less labor; improvement in organizational and departmental techniques; management of day-to day activities. Three factors has been identified; technological factor, organizational factor and people factor. In technological dimension, three variables are suggested: system quality, information quality, and service quality. In organizational dimension, two variables are suggested: top management support, and end-user training. In people dimension, two variables are suggested: computer self-efficacy, and user experience. 
INTERNATIONAL JOURNAL OF ACADEMIC RESEARCH IN BUSINESS AND SOCIAL SCIENCES Vol. 8, No. 9, Sept. 2018, E-ISSN: 2222-6990 @ 2018 HRMARS

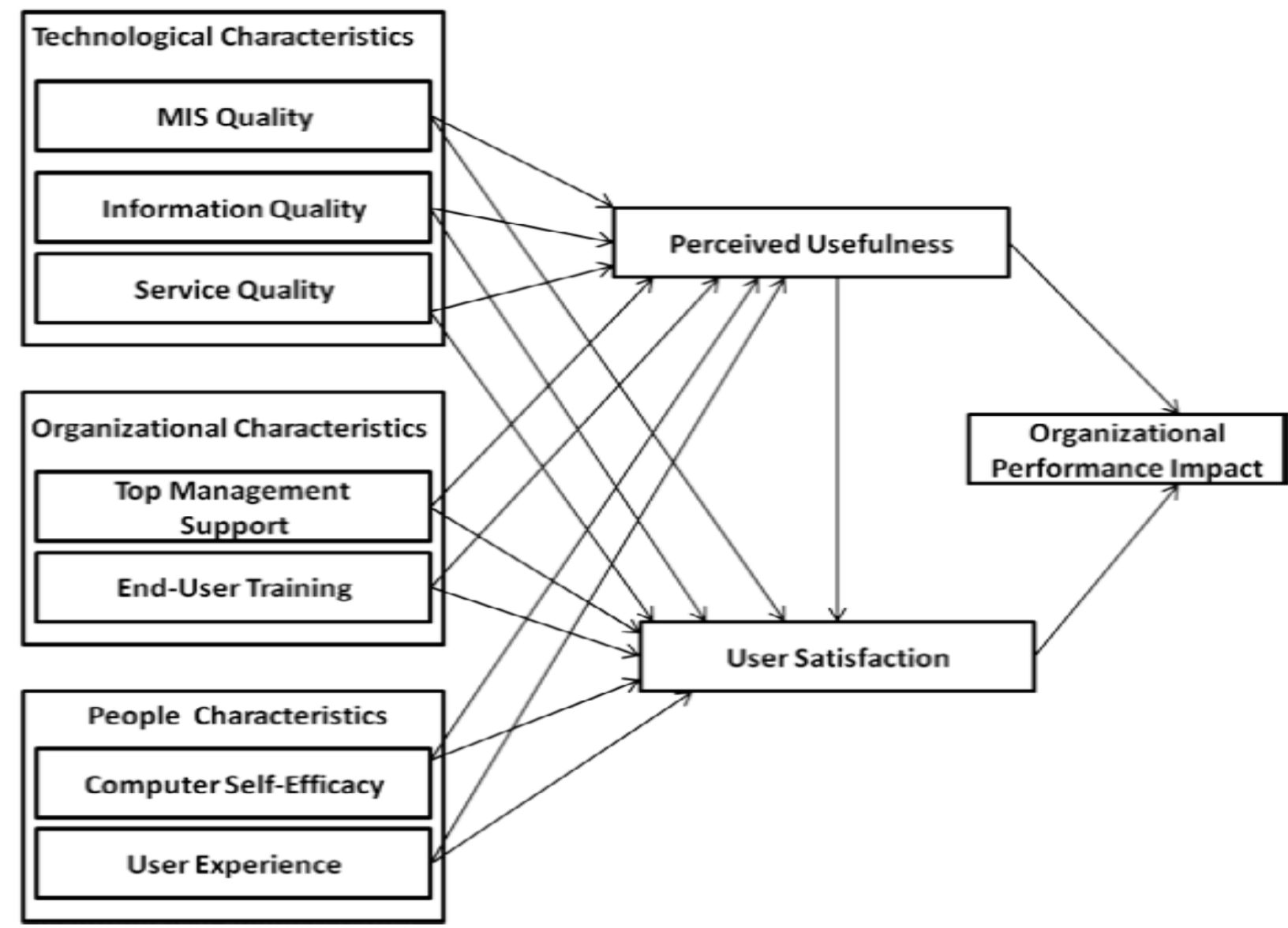

Figure 3: Theoretical framework by Al-mamary et al. (2014a)

In addition, study by Yunis et al. (2017) focuses on ICT adoption has become major driver of enhanced organizational performance. In this research reveal an important explanation of the relationship between ICT use and performance. Technology adoption is only important if it truly leads to performance improvements and, as such, we argue that the proper criteria by which to judge whether an ICT investment has been successful rest not simply in determining whether an organization adopts a technology, but whether the technology application or use actually improves performance. ICT by itself cannot contribute to significant performance improvement or sustainable competitive advantage if organizational resources and work processes are not improved or changed to enable ICT to promote organizational performance.

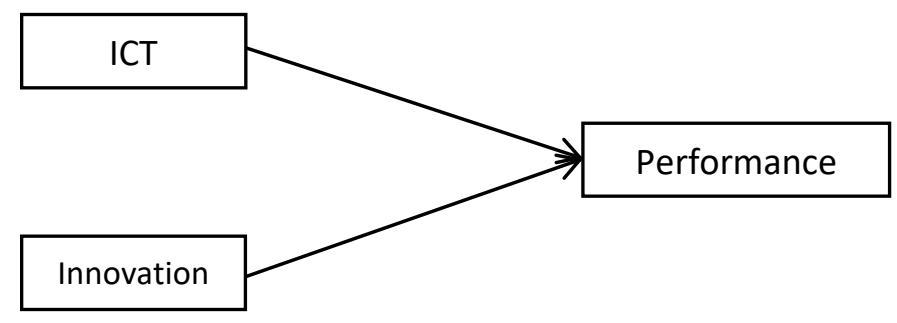

Figure 4: Research Model by (Yunis et al., 2017) 
INTERNATIONAL JOURNAL OF ACADEMIC RESEARCH IN BUSINESS AND SOCIAL SCIENCES Vol. 8, No. 9, Sept. 2018, E-ISSN: 2222-6990 @ 2018 HRMARS

There is a shortcoming when it comes to evaluate the organizational by incorporating OSS usage. Yunis et al (2017) developed a model to evaluate organizational performance. The authors evaluate the performance based on ICT and innovation. In Al-Mamary et al. (2014a), the authors focuses on technology, people and organizational characteristic in order to analyse their satisfaction toward their organizational performance. At the same time, Yaseen \& Bahari (2014) applied Fitzgerald Framework to evaluate the adoption of OSS in every organizational structure level. Johnson et al (2013) applied an OS adopted model on Technology Organization Environment. Compare to the previous study, there are still some limitations and gaps on the framework based OSS to evaluate the organizational goal performance as shown in Table 1. Despite this shortfall, we adopt technology, organizational and environmental aspects in order to evaluate the usefulness of OSS in organization.

\begin{tabular}{lcccc}
\hline Authors & OSS Adoption & Technology & Innovation & $\begin{array}{l}\text { Organizational } \\
\text { Performance }\end{array}$ \\
\hline Yunis et al (2017) & & $/$ & $/$ & $/$ \\
Al-Mamary et al. & & & & \\
(2014a) & $/$ & & \\
Yaseen \& Bahari (2014) & $/$ & & & \\
Johnson et al (2013) & $/$ & & \\
\hline
\end{tabular}

Table 1: Review on the OSS adoption toward organizational performance

\section{Propose Theoretical Framework}

Organizational performance is a major aspect as a measurement to evaluate the organizational goal achievement. The implication of technology is important to integrate between available systems in organization. As organization structure always changes, it is important to adopt technology that can cope with change in organization environment. Most of the previous study discusses the concept and theory rather than the implementation of OSS in line with organizational performance. In contrast to the previous study, we proposed a framework based OSS usage in relation to the organizational performance. In this framework, it is important to measure the usage of OSS by integrating technology, organizational and environmental. 


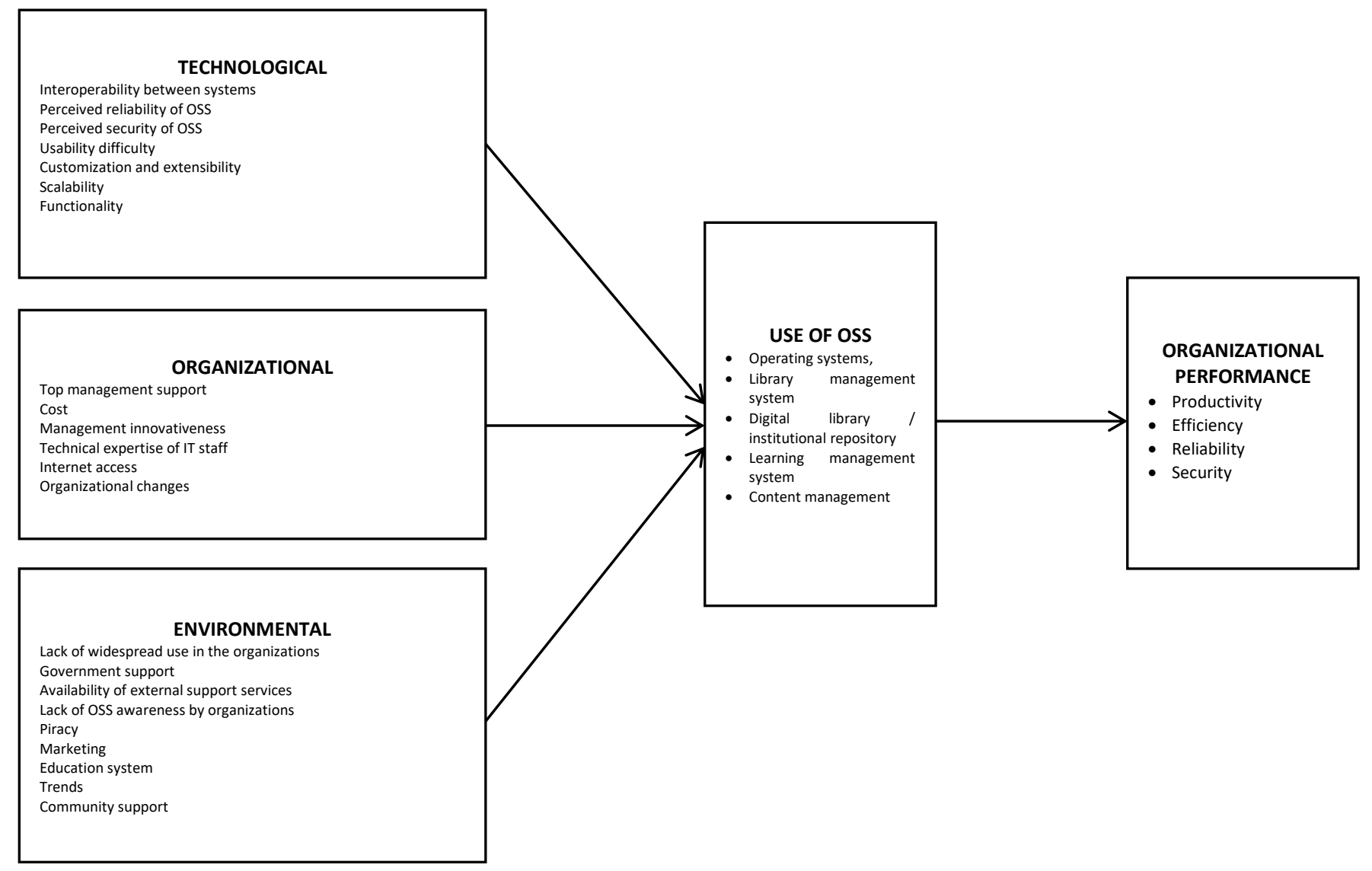

\section{CONCLUSION}

OSS is capable to extend organizational performances as it is an opportunity for the organization to adopt with current change and to emerge IR 4.0 significantly. Every organization such library must aware the dynamic of technology such as OSS across their organization. However, it is important for organization to be carefully during selection and customization an appropriate OSS as it might address specific business requirement in relation to the organizational performance. In this paper, the proposed framework will associate organization competitive edge throughout their ability to improve their performance.

\section{REFERENCES}

Al-mamary, Y. H., Shamsuddin, A., \& Aziati, N. (2014a). Factors Affecting Successful Adoption of Management Information Systems in Organizations towards Enhancing Organizational Performance. American Journal of Systems and Software, 2(5), 121-126. https://doi.org/10.12691/ajss-2-5-2

Al-mamary, Y. H., Shamsuddin, A., \& Aziati, N. (2014b). The Relationship between System Quality, Information Quality, and Organizational Performance. International Journal of Knowledge and Research in Management \& E-Commerce, 4(3), 7-10.

Alex, K. (2015). Impact of Information Technology on Organizational Performance: Case of Population Services Kenya.

Ani, O. E., Esin, J. E., \& Edem, N. (2005). Adoption of information and communication technology (ICT) 
INTERNATIONAL JOURNAL OF ACADEMIC RESEARCH IN BUSINESS AND SOCIAL SCIENCES

Vol. 8, No. 9, Sept. 2018, E-ISSN: 2222-6990 @ 2018 HRMARS

in academic libraries A strategy for library networking in Nigeria. The Electronic Library, 23(6), 701-708. https://doi.org/10.1108/02640470510635782

Anjaneyulu, P., Biradar, K., Gopinath, S., \& Naik, K. J. (2017). Awareness and Use of Open Source Software Among The Library Professionals in Bangalore City: A Study. In 11th International CALIBER-2017 (pp. 388-392).

Awuor, F. M., Rabah, K., \& Maake, B. M. (2016). Hindrance of ICT Adoption to Library Services in Higher Institution of Learning in Developing Countries. Computer Science and Information Technology, 1(4), 252-256. https://doi.org/10.13189/csit.2013.010403

Bindura, J. P. C. (2018). Adoption of Open Source Software in Libraries in Developing Countries. International Journal of Library and Information Services, 7(March), 0-17. https://doi.org/10.4018/IJLIS.2018010102

Bryman, A. (2012). Social Research Methods, 4th Edition.

Buffett, B. (2014). Factors influencing open source software adoption in public sector national and international statistical organisations.

Canadian Association of Research Libraries. (2010). Core competencies for 21 st Century CARL librarians.

Chengalur-smith, I., Nevo, S., \& Demertzoglou, P. (2010). An Empirical Analysis of the Business Value of Open Source Infrastructure Technologies. Journal of the Association for Information Systems, 11(11), 708-729.

Eclipse Foundation. (2017). Open Source Software for Industry 4.0 (Vol. 2017).

Gichira, C. M., Miriti, K., \& Kahonge, A. M. (2012). Adoption of Open Source Software by Organizations A Framework for Kenya. International Journal of Computer Applications, 59(7), 25-32. https://doi.org/10.5120/9561-4030

Gurusamy, K., \& Campbell, J. (2011). A Case Study Of Open Source Software Adoption In Australian Public Sector Organisations. In PACIS 2011 Proceedings.

Hamid, A., Abdullah, N. L., \& Idrus, R. (2016). Framework for Successful Open Source Software Implementation in the Malaysian Public Sector. In 2016 International Conference On Advanced Informatics: Concepts, Theory And Application (ICAICTA) (pp. 1-6). George Town.

Hanumappa, A., Dora, M., \& Navik, V. (2014). Open Source Software solutions in Indian libraries. Library Hi Tech, 32(3), 409-422. https://doi.org/10.1108/LHT-12-2013-0157

Jean, R. B., Sinkovics, R. R., \& Kim, D. (2008). Information technology and organizational performance within international business to business relationships A review and an integrated conceptual framework. International Marketing Review, 25(5), 563-583. https://doi.org/10.1108/02651330810904099

Johnston, K., Begg, S., \& Tanner, M. (2013). Exploring the factors influencing the adoption of Open Source Software in Western Cape schools. International Journal of Education and Development Using Information and Communication Technology, 9(2), 64-84.

Jusoh, Y. Y., Chamili, K., Yahaya, J. H., \& Pa, N. C. (2012). The Selection Criteria of Open Source Software Adoption in Malaysia. International Journal of Advancements in Computing Technology, 4(21), 278-287. https://doi.org/10.4156/ijact.vol4.issue21.33

Leeladharan, M. (2015). Open Source Software Awareness and Use by The Library Professional of Professional Colleges in Puducherry. International Journal of Digital Library Services, 1142(1), 130-139.

MAMPU. (2006). Open Source Software (OSS) Implementation Guidelines Malaysian Public Sector Open Source Software (OSS). 
INTERNATIONAL JOURNAL OF ACADEMIC RESEARCH IN BUSINESS AND SOCIAL SCIENCES

Vol. 8, No. 9, Sept. 2018, E-ISSN: 2222-6990 @ 2018 HRMARS

Marsan, J., \& Paré, G. (2013). Antecedents of open source software adoption in health care organizations: A qualitative survey of experts in Canada. International Journal of Medical Informatics, 82(8), 731-741. https://doi.org/10.1016/j.ijmedinf.2013.04.001

Mijinyawa, M. K., \& Abdulwahab, L. (2014). Evaluating the Adoption of Open Source Software. British Journal of Applied Science \& Technology, 4(34), 4816-4834. https://doi.org/10.9734/BJAST/2014/12504

Murphy, S., \& Cox, S. (2015). Understanding Open Source Adoption in UK Small and Medium Sized Businesses: Gap or Chasm? Journal of CEBE, 2(1), 59-70.

Mutula, S., Kalaote, T., \& Mutula, S. (2010). Open source software deployment in the public sector: a review of Botswana and South Africa. Library Hi Tech, 28(1), 63-80. https://doi.org/10.1108/07378831011026698

Neuman, W. L. (2006). Social research methods: Qualitative and quantitative approaches.

Njoku, I. S. (2017). Use of Open Source Technology for Effective Academic Library Services in Nigeria. Library Philosophy and Practice (E-Journal).

O'Shaughnessy, L. (2012). The College Solution: A Guide for Everyone Looking for the Right School at the Right Price.

Oguche, D. (2017). Impact of Information and Communication Technology (ICT) Literacy competence on Job Performance of Librarian in Federal University Libraries in Nigeria. The Information Technologist, 13(1).

Oyelude, A. A. (2016). Open source software for library systems - 1. Library Hi Tech News, 33(5), 13. https://doi.org/10.1108/LHTN-05-2016-0023

Pickard, A. J. (2013). Research Methods in Information.

Randhawa, S. (2008). Open Source Software and Libraries. In Trends and Strategic Issues for Libraries in Global Information Society (pp. 369-377).

Reddy, C. S. V. (2013). Comparative Study of Free / Open Source Integrated Library Management Systems (FOSILMS) with Reference to KOHA, NewGenLib and E-Granthalaya. E-Library Science Research Journal, 1(12), 1-10.

Singh, V. (2013). Experiences of Migrating to an Open- Source Integrated Library System. Information Technology and Libraries, (March), 36-53.

Thanasopon, B. (2015). Open Source Software (OSS) Adoption in Commercial Firms: A Literature Review. KMITL Information Technology Journal.

Uzomba, E. C. (2015). The Use and Application of Open Source Integrated Library System in Academic Libraries in Nigeria : Koha Example. Library Philosophy and Practice.

Wei, Z. (2011). Research on the Application of Open Source Software in Digital Library. Procedia Engineering, 15, 1662-1667. https://doi.org/10.1016/j.proeng.2011.08.310

Yaseen, M. G., \& Bahari, M. (2014). A Theoretical Research Framework of Open Source Software Adoption in Malaysian University Information and Communications Technology Centers. Journal of Information System, 8, 75-82.

Yunis, M., Tarhini, A., \& Kassar, A. (2017). The role of ICT and innovation in enhancing organizational performance: The catalysing e ff ect of corporate entrepreneurship. Journal of Business Research, (June). https://doi.org/10.1016/j.jbusres.2017.12.030 